\title{
Ingestive behavior of finishing sheep fed detoxified castor bean meal ${ }^{1}$
}

\author{
Daniel Cézar da Silva ${ }^{2 *}$, Beatriz Dantas Fernandes ${ }^{3}$, Jéssica Monique dos Santos Lima, \\ Francisco Jocélio Cavalcante de Souza ${ }^{3}$, Miguel Arcanjo Moreira Filho ${ }^{4}$, Arnaud Azevêdo Alves ${ }^{4}$
}

$10.1590 / 0034-737 X 201663030007$

\begin{abstract}
Castor bean crops stand out in the Northeastern Brazil for oil production, producing coproducts with potential for animal diets. Thus, this work evaluated the effect on ingestive behavior when 0, 33, 67 and 100\% of detoxified castor bean meal (DCBM) were included to substitute soy bean meal in diets for sheep. The randomized blocks design was used with five sheep in each treatment. Dry matter intake and neutral detergent fiber intake were not affected $(\mathrm{P}>.05)$ by the inclusion of DCBM in the diet, with means of 1362.6 and $582.98 \mathrm{~g} / \mathrm{animal} /$ day, respectively. Substitution of soybean meal by DCBM did not affect $(\mathrm{P}>.05)$ times of rumination, idle and total chewing, with averages of $181.33,347.04$ and 366.24 minute/12 h, respectively. A quadratic effect $(\mathrm{P}<.05)$ was found for feeding time, with minimum of $164.56 \mathrm{~min} / 12$ $\mathrm{h}$, when $60 \%$ of DCBM was included in the diet. A quadratic effect $(\mathrm{P}<.05)$ was verified for eating efficiency with maximum of $4.43 \mathrm{~g} \mathrm{DM} /$ minute and $2.08 \mathrm{~g} \mathrm{NDF} /$ minute. Rumination efficiency in $\mathrm{g} \mathrm{DM}$ and NDF/minute were not affected $(\mathrm{P}<.05)$, with means of 4.31 and 1.84, respectively. The substitution of soybean meal by DCBM decreases feeding time when $60 \%$ of it was used but does not influence the intake of DM and NDF, time spent in ruminating and idle, and total chewing time. The use of $60 \%$ of DCBM increases feeding efficiency of DM and NDF, and does not compromise the efficiency of rumination.
\end{abstract}

Key words: coproducts, eating time, Ricinus communis, voluntary intake.

\section{RESUMO}

\section{Comportamento ingestivo de ovinos em terminação alimentados com farelo de mamona destoxificado}

A cultura da mamona destaca-se, no nordeste do Brasil, para a produção de óleo, gerando coprodutos com potencial para a alimentação animal. Por essa razão, avaliou-se, neste trabalho, o efeito sobre o comportamento ingestivo da inclusão de 0;33; 67 e 100\% do farelo de mamona destoxificado (FMD) em substituição ao farelo de soja, em dietas para ovinos. Foi adotado o delineamento de blocos ao acaso, com cinco ovinos por tratamento. Os consumos de MS e FDN não foram influenciados (P > 0,05) pela participação do FMD na dieta, com médias de 1362,6 e 582,98 g/animal/dia, respectivamente. A substituição do farelo de soja pelo FMD não influenciou $(\mathrm{P}>0,05)$ os tempos de ruminação, de ócio e de TMT, com média de 181,33; 347,04 e 366,24 min/12 h, respectivamente. Verificou-se efeito quadrático $(\mathrm{P}<0,05)$ para o tempo em alimentação, com mínima de 164,56 min/12 h, quando da participação de $60 \%$ de FMD na dieta. Houve efeito quadrático $(\mathrm{P}<0,05)$ para a eficiência de alimentação, com máximas de 4,43 g MS/min e 2,08 g FDN/min, quando da participação de 58,8 e 69,5\%, respectivamente, do FMD nas dietas. A eficiência de ruminação em g MS e FDN/min não

\footnotetext{
Submitted on July $25^{\text {th }}, 2014$ and accepted on January $20^{\text {th }}, 2016$. 
foi influenciada ( $\mathrm{P}>0,05)$, com médias de 4,31 e 1,84, respectivamente. A substituição do farelo de soja pelo FMD diminui o tempo em alimentação quando da utilização em $60 \%$, mas não influencia o consumo de MS e FDN, o tempo despendido em ruminação, em ócio, e o TMT. O uso de $60 \%$ de FMD eleva a eficiência de alimentação de MS e FDN e não compromete a eficiência de ruminação.

Palavras-chave: consumo voluntário, coprodutos, Ricinus communis, tempo em alimentação.

\section{INTRODUCTION}

The increase in the Brazilian demand for biodiesel as an alternative energy source has significantly raised the availability of co-products such as cakes, meals and bark, from the extraction of oil seed oils. In this scenario, the livestock sector is strategically positioned to use these potential feeds, which often represent low cost sources of protein and energy (Oliveira et al., 2010).

Among the several oil seed species, castor bean (Ricinus communis L.) has stood out in the Northeast region for representing an important promoter of economic and social development of small farmers (Brasil, 2005), a fact that was highlighted in 2008 when the inclusion of biodiesel in the composition of fossil diesel became compulsory, as determined by the National Programme for Production and Use of Biodiesel (ANP, 2009).

This determination has expanded the availability of coproducts of the extraction of oil from castor bean seeds, which, combined with the nutritional potential of these alternative ingredients, has allowed greater use for feeding purposes, as verified by Gowda et al. (2008), who found no differences between the control diet and those based on castor bean, obtaining from that the digestibility of dry matter, neutral detergent fiber and crude protein of 61.3; 58.6 and $58.1 \%$, respectively.

According to Silva et al. (2010), providing detoxified castor meal to sheep in finishing did not affect intake, fecal and urinary excretion, nitrogen absorption and retention by an average of $26.70 ; 10.9 ; 17.96$ and $15.78 \mathrm{~g} / \mathrm{day}$, respectively, recommending the use of this co-product for feeding sheep, as it does not influence ruminal $\mathrm{pH}$, the concentration of $\mathrm{N}_{-} \mathrm{NH}_{3}$ in the rumen fluid and urea in blood serum.

Despite these results, animal performance cannot be assessed without taking into account the aspects of ingestive behavior, which are essential to the nutrient intake, digestibility and other nutritional parameters. According to Silva et al. (2004), the factors that affect ingestive behavior are linked to the diets, the environment and to the animal, with greater relevance to the first factor, especially when using agro-industrial co-products, which usually have variations in chemical composition or antinutritional factors.
For the co-products of castor bean, the restriction of use in animal nutrition is attributed to the presence of antinutritional factors, ricin, ricinine, complex allergen CB1A (Aslani et al., 2007), but can be inactivated by detoxification processes, by temperature and pressure treating of the bran, in association or not with chemical agents (Anandan et al., 2005).

Therefore, because it presents these characteristics, the need for studying ingestive behavior of sheep fed detoxified castor meal is justified since this tool allows evaluation of diets aiming at adjusting the feeding management of animals, in order to obtain better performance, compared to the use of unconventional diets.

The objective of this study was to evaluate the effect of substituting soybean meal on by detoxified castor meal the ingestive behavior of sheep in finishing.

\section{MATERIAL AND METHODS}

The experiment was conducted at Departamento de Zootecnia (DZO) of the Centro de Ciências Agrárias (CCA) of the Universidade Federal do Piauí (UFPI) in Teresina, state of Piauí, located at coordinates $05^{\circ} 02^{\prime} 28^{\prime \prime} \mathrm{S}$, and $42^{\circ} 46^{\prime} 57$ " W, altitude of $71.3 \mathrm{~m}$.

Total isoprotein and isoenergy diets were evaluated for sheep in finishing. Those diets contained castor bean meal substituting soybean meal at levels 0,33, 67 and 100\%, on the dry matter basis. The diets were composed by elephant grass (Pennisetum purpureum Schum.) cv. Roxo hay, processed at 90 days of sprout, and concentrate composed disintegrated corn grain, soybean meal, urea, mineral vitamin supplement and castor bean meal, detoxified by autoclaving at $121^{\circ} \mathrm{C}$ under pressure of 15 psi for one hour (Anandan et al., 2005), with the chemical composition shown in Table 1, aimed at meeting the nutritional requirements recommended by the NRC (2007) for average daily gain of $200 \mathrm{~g}$ (Table 1 ).

After that, an in vivo metabolism trial was carried out, using 20 Santa Inês crossbred sheep, not castrated, with initial body weight of $35 \pm 5 \mathrm{~kg}$ at eight months of age, in good health and nutritional status, kept in cages of metabolism study, with dimensions of $1.0 \times 0.5 \mathrm{~m}$. Animals were fed experimental diets offered at 8 a.m. and 4 p.m., which were provided so to provide $15 \%$ of leftovers 
compared to the consumption on the previous day, besides providing water ad libitum.

In the beginning of the experiment period, the animals were weighed after fasting, for distribution in treatments according to a randomized block design with four treatments (diets) and five repetitions (sheep), adopting the change in body weight in the beginning of the experiment for distribution of animals in the five blocks.

To determine the intake, the in vivo total collection method of leftovers was used for seven days, preceded by a period of 14 days for the animals to get adapted to experimental conditions. The leftovers were collected before each meal, withdrawing an aliquot of $20 \%$, which were then placed in plastic bags and stored in a freezer $\left(-5\right.$ to $\left.-10^{\circ} \mathrm{C}\right)$. At the end of the collection period, samples of the leftovers were defrosted, homogenized and composite samples per animal were formed. The daily intake of dry matter and nutrients was estimated by the difference between the offered diet and leftovers.

Samples were analyzed at the Laboratório de Nutrição Animal (LANA) of the Departamento de Zootecnia (DZO / CCA / UFPI). Samples of leftovers were dried at $55^{\circ} \mathrm{C}$ in an oven with forced air circulation for 72 hours and ground in a Wiley-type mill to reduce them to 1-mm particles. Contents of dry matter (DM) were determined and, based on them, the neutral detergent fiber (NDF), according to methods described by Silva \& Queiroz (2002).

The evaluation of the ingestive behavior of sheep was performed for three consecutive days, during the experimental period, quantifying the time spent in feeding, ruminating and idle for 12 hours per day, according to the adaptation of the methodology of Macedo et al. (2007).

Observations were carried out from 6 a.m. to 6 p.m. at every 30 minutes, using scam sampling by four trained observers in a turn system, strategically placed so not to disturb the animals.

Ingestive behavior parameters, the time spent eating, ruminating and idle, were expressed in minutes $/ 12 \mathrm{~h}$, while the feeding efficiency (FE) and rumination efficiency (RE) were expressed in grams of dry matter (DM) and neutral detergent fiber (NDF) per minute/12 h, calculated by the following relationships: $\mathrm{FE}_{\mathrm{DM}}=\mathrm{DMI} / \mathrm{FT}$ and $\mathrm{FE}_{\mathrm{NDF}}=\mathrm{NDF} /$ $\mathrm{FT}, \mathrm{FE}_{\mathrm{DM}}=\mathrm{DMI} / \mathrm{RT}$ and $\mathrm{RENDF}=\mathrm{NDF} / \mathrm{RT}$, where $\mathrm{DMI}=$ daily dry matter intake $(\mathrm{g})$; NDF = daily neutral detergent fiber intake (g), TF = time spent in feeding minute/12 hours and $\mathrm{RT}=$ time spent ruminating minute $/ 12 \mathrm{~h}$.

The total chewing time (TCT minute/12 h) was obtained using the formula: $\mathrm{TCT}=\mathrm{FT}+\mathrm{RT}$ where $\mathrm{FT}=$ time spent in feeding minute $/ 12 \mathrm{~h}$ and $\mathrm{RT}=$ time spent in rumination minute $/ 12 \mathrm{~h}$.

Data were analyzed according to PROC MEANS procedure of SAS statistical software (2001), carrying out descriptive statistics for means, standard deviation and coefficient of variation. Regression analysis was performed using the PROC GLM where the parameters of feeding behavior were considered as dependent variables and the substitution levels $0 ; 33 ; 67$ and $100 \%$ of detoxified castor bean meal substituting soybean meal as independent variables for the construction of the models.

Table 1: Percent and bromatological composition of diets with detoxified castor bean meal substituting soybean meal

\begin{tabular}{|c|c|c|c|c|}
\hline \multirow{2}{*}{ Ingredient/Nutrient } & \multicolumn{3}{|c|}{ Detoxified castor bean meal (DCM \%) } & \multirow[b]{2}{*}{100} \\
\hline & $\mathbf{0}$ & 33 & 67 & \\
\hline \multicolumn{5}{|c|}{ Percent composition } \\
\hline Elephant-grass hay & 39.57 & 37.83 & 38.19 & 38.00 \\
\hline Corn & 43.37 & 42.38 & 42.07 & 42.07 \\
\hline Soybean meal & 14.30 & 9.57 & 4.76 & 0.00 \\
\hline Castor bean meal & 0.00 & 4.74 & 9.51 & 14.27 \\
\hline Urea & 0.294 & 0.473 & 0.475 & 0.665 \\
\hline Mineral mixture & 5.00 & 5.00 & 5.00 & 5.00 \\
\hline \multicolumn{5}{|c|}{ Chemical composition } \\
\hline Dry matter (DM, \%) & 93.19 & 93.38 & 93.53 & 93.56 \\
\hline Mineral matter (\% of DM) & 9.75 & 9.71 & 10.46 & 11.21 \\
\hline Crude protein $(\%$ of $\mathrm{DM})$ & 13.62 & 13.45 & 12.69 & 11.89 \\
\hline Ether extract (\% of DM) & 2.26 & 2.53 & 3.44 & 3.72 \\
\hline TCHO* & 74.37 & 74.30 & 73.41 & 73.18 \\
\hline NFC* & 35.82 & 30.80 & 30.36 & 32.56 \\
\hline Neutral detergent fiber (\% of DM) & 38.54 & 43.50 & 43.05 & 40.62 \\
\hline Acid detergent fiber (\% of DM) & 19.46 & 21.96 & 24.27 & 26.05 \\
\hline Gross energy (Mcal/kg DM) & 4.19 & 4.19 & 4.24 & 4.23 \\
\hline Total digestible nutrients ( $\%$ of $\mathrm{DM})$ & 64.74 & 64.64 & 64.69 & 61.37 \\
\hline
\end{tabular}

$* \mathrm{TCHO}=$ total carbohydrates and $* \mathrm{NFC}=$ non-fibrous carbohydrates, estimated according to Sniffen et al. (1992). 


\section{RESULTS AND DISCUSSION}

Dry matter $(\mathrm{DM})$ intake was not influenced $(\mathrm{P}>.05)$ by the replacement of soybean meal by detoxified castor bean meal (DCBM) in diets, with means of $1362.6 \mathrm{~g} /$ animal/day (Table 3), which allowed meeting nutritional requirements for DM intake established by the NRC (2007), of $1003.00 \mathrm{~g} /$ day.

The values obtained in this study for DM intake corroborate those verified by Vieira et al. (2011), who found no significant difference for this parameter when substituting soybean meal by detoxified castor bean meal at the levels of $0 ; 50 ; 75$ and $100 \%$ with respective means of 1550; 1490; 1530 and $1490 \mathrm{~g} / \mathrm{animal} / \mathrm{day}$, confirming that the use of this co-product in the feeding of sheep does not limit DM intake.

The substitution of soybean meal by detoxified castor bean meal did not affect neutral detergent fiber (NDF) intake (P > .05) (Table 2), with a mean of $582.98 \mathrm{~g} / \mathrm{animal} /$ day. When NDF intake was related to body weight, it was found that its amount corresponded to $1.47 \%$ of body weight and did not affect dry matter intake.
The average levels of NDF in the diets, from $41.43 \%$ in DM (Table 1), with $28.17 \%$ of NDF from the roughage, and NFC of $33.63 \%$ in the DM, denoting an adequate diet to a good stability of fermentation conditions in the rumen. Levels of NDF in the experimental diets can be considered high; however, they did not affect the intake parameters of $\mathrm{DM}$ and $\mathrm{OM}$, considered determinants of animal performance, unlike that verified by Cardoso et al. (2006), in whose work, the rise of dietary NDF levels impaired the intake of DM and nutrients.

The time spent in rumination and idle, and the total chewing time (TCT) were not influenced $(\mathrm{P}>.05)$ by the participation of detoxified castor bean meals in the diets, with means of 181.33; 347.04 and 366.24 minutes/12 h respectively, contrary to time spent in feeding, which was influenced $(\mathrm{P}<$ $.05)$ and resulted in a quadratic effect $(\mathrm{P}<.05)$, with a minimum of 164.56 minutes $/ 12 \mathrm{~h}$, when $60 \%$ of detoxified castor bean meal was included in the diet (Table 2).

The reduction in the time spent in the feeding, due to the greater participation of that meal from the referred co-

Table 2: Means and regression equations for DM and NDF intake (g/animal/day), time spent in feeding, rumination, idle and total chewing time (TCT) (minutes/12 h), feeding and rumination efficiency (g DM and NDF/minute and h/12 h) in sheep fed diets containing detoxified castor bean meal substituting soybean meal.

\begin{tabular}{|c|c|c|c|c|c|c|c|}
\hline \multirow{2}{*}{ Parameter } & \multicolumn{4}{|c|}{ Detoxified castor bean meal (DCM \%) } & \multirow{2}{*}{ Mean \pm deviation } & \multirow{2}{*}{$\mathbf{R}^{2}$} & \multirow{2}{*}{$\mathrm{CV}(\%)$} \\
\hline & $\mathbf{0}$ & 33 & 67 & 100 & & & \\
\hline DM intake & 1323.08 & 1372.12 & 1445.68 & 1309.43 & $1362.6 \pm 212.3^{\mathrm{NSa}}$ & - & 15.65 \\
\hline NDF intake & 560.14 & 572.59 & 643.00 & 556.18 & $582.98 \pm 90.46^{\mathrm{NS}}$ & - & 14.80 \\
\hline Feeding & 253.44 & 172.80 & 174.72 & 199.68 & $1 * \mathrm{~b}$ & 0,66 & 18.81 \\
\hline Rumination & 79.69 & 83.70 & 88.67 & 89.83 & $181.33 \pm 64.66^{\mathrm{NS}}$ & - & 18.59 \\
\hline Idle & 330.24 & 341.76 & 391.68 & 324.48 & $347.04 \pm 70.04^{\mathrm{NS}}$ & - & 13.01 \\
\hline TCT & 389.76 & 351.36 & 328.32 & 395.52 & $366.24 \pm 87.43^{\mathrm{NS}}$ & - & 15.97 \\
\hline \multicolumn{8}{|c|}{ Feeding efficiency } \\
\hline gMS/min & 2.67 & 4.18 & 4.25 & 3.49 & $2 *$ & 0.61 & 20.37 \\
\hline$g M S / h$ & 160.47 & 250.98 & 255.05 & 209.48 & $3 *$ & 0.60 & 20.33 \\
\hline$g$ FDN/min & 1.12 & 1.78 & 1.89 & 1.47 & $4 *$ & 0.64 & 19.08 \\
\hline$g F D N / h$ & 67.42 & 106.57 & 113.53 & 88.47 & $5 *$ & 0.66 & 18.97 \\
\hline \multicolumn{8}{|c|}{ Rumination efficiency } \\
\hline gMS/min & 4.51 & 3.4 & 4.94 & 4.26 & $4.31 \pm 1.51^{\mathrm{NS}}$ & - & 18.05 \\
\hline$g M S / h$ & 270.76 & 203.76 & 296.36 & 255.44 & $258.73 \pm 111.70^{\mathrm{NS}}$ & - & 18.08 \\
\hline$g \mathrm{FDN} / \mathrm{min}$ & 1.90 & 1.41 & 2.19 & 1.77 & $1.84 \pm 0.67^{\mathrm{NS}}$ & - & 19.22 \\
\hline$g F D N / h$ & 114.12 & 84.93 & 131.66 & 106.34 & $110.34 \pm 47.55^{\mathrm{NS}}$ & - & 19.20 \\
\hline \multicolumn{8}{|l|}{ Periods } \\
\hline Feeding & 8.80 & 6.0 & 6.07 & 6.93 & 6* & 0.66 & 22.82 \\
\hline Rumination & 5.58 & 7.59 & 5.33 & 6.80 & $6.30 \pm 2.43$ & & 28.61 \\
\hline Idle & 11.47 & 11.87 & 13.60 & 11.27 & $12.05 \pm 2.77$ & - & 23.01 \\
\hline \multicolumn{8}{|c|}{$\begin{array}{l}{ }^{a} \mathrm{NS}=\text { not significant; }{ }^{b} *=\mathrm{P}<0.05 \\
{ }^{1} \mathrm{v}=250.3621-2.8641 \mathrm{DCM}+0.0239 \mathrm{DCM}^{2} \\
{ }^{2} \mathrm{v}=2.7063+0.0588 \mathrm{DCM}-0.0005 \mathrm{DCM}^{2} \\
{ }^{3} \mathrm{v}=162.3895+3.5291 \mathrm{DCM}-0.0308 \mathrm{DCM}^{2} \\
{ }^{4} \mathrm{v}=1.1226+0.0278 \mathrm{DCM}-0.0002 \mathrm{DCM}^{2} \\
{ }^{5} \mathrm{v}=67.4489+1.6619 \mathrm{DCM}-0.0145 \mathrm{DCM}^{2} \\
{ }^{6} \mathrm{v}=8.6933-0.0995 \mathrm{DCM}+0.0008 \mathrm{DCM}^{2}\end{array}$} \\
\hline
\end{tabular}


Table 3: Chemical composition of the ingredients in the experimental diets

\begin{tabular}{lcccc}
\hline \multirow{2}{*}{ Nutrient } & \multicolumn{4}{c}{ Ingredient } \\
\cline { 2 - 5 } & $\begin{array}{c}\text { Elephant } \\
\text { grass hay }\end{array}$ & $\begin{array}{c}\text { Soybean } \\
\text { meal }\end{array}$ & $\begin{array}{c}\text { Detoxified castor } \\
\text { bean meal }\end{array}$ & Corn \\
\hline Dry matter (DM, \%) & 89.10 & 87.95 & 91.25 & 88.58 \\
Mineral matter (\% of DM) & 9.67 & 7.23 & 15.64 & 1.17 \\
Crude Protein (\% of DM) & 5.50 & 52.97 & 30.93 & 8.86 \\
Ether extract (\% of DM) & 1.96 & 1.41 & 10.29 & 4.36 \\
TCHO* & 82.86 & 38.38 & 43.13 & 73.60 \\
NFC* & 9.48 & 25.10 & 4.87 & 12.29 \\
Neutral detergent fiber (\% of DM) & 73.38 & 13.27 & 38.26 & 3.24 \\
Acid detergent fiber (\% of DM) & 45.18 & 9.59 & 33.46 & \\
\hline
\end{tabular}

*TCHOT $=$ total carbohydrates and $* \mathrm{NFC}=$ non-fiber carbohydrates, estimated according to Sniffen et al. (1992).

product in the diets, may be attributed to the significant difference in NDF content between soybean meal (13.27\% DM) and detoxified castor bean meal (38.26\% DM) (Table 3 ), which conditioned greater effect of NDF on feeding time, resulting in an increase in the time spent for the performing this ingestive activity.

These results are confirmed by observations of Hübner et al. (2008), who found a decrease in time spent in feeding, from 255.00 minutes/day to 222.50 minutes/day when the level of NDF was increased from 43 to $52 \%$, on a dry matter basis in the diet of lactating ewe.

In the evaluations of the ingestive behavior of Morada Nova crossbred sheep, fed diets containing levels of detoxified castor bean meal similar to those evaluated in this study, Vieira et al. (2011) found an interaction between the evaluation periods and the time spent in activities of feeding, rumination and idle. In this situation, the shortest feeding time was observed in animals receiving diets with 0 and $100 \%$ of substitution of soybean meal by detoxified castor bean meal, in the period from 17 to 20 hours.

Carvalho et al. (2006), when evaluating ingestive behavior of Santa Inês sheep fed co-products, found no effect on the parameters of ingestive behavior, with the animals remaining at $22.16 ; 43.77$ and $34.06 \%$ of the time eating, ruminating and at idle, respectively, contrary to what happened in this study, in which the time spent in feeding activities represented $27.8 \%$; the rumination time was $25.18 \%$ and the idle time was $48.2 \%$.

Feeding efficiency in function of the DM and NDF were influenced $(\mathrm{P}<.05)$ by the substitution of soybean meal by detoxified castor bean meal, which resulted in a quadratic effect, with maximums of $4.43 \mathrm{~g} \mathrm{DM} /$ minute and $2.08 \mathrm{~g} \mathrm{NDF} / \mathrm{minute}$ when 58.8 and $69.5 \%$ of detoxified castor bean meal were included in the diet, respectively (Table 2).

The rise in feeding efficiency for DM and NDF at the substitution levels previously mentioned, shows that the detoxified castor bean meal does not seem to compromise the feeding behavior, because even with the reduction in time spent in feeding, the feeding efficiency has not decreased, indicating that animals compensated for the shortest time spent on feeding activity, keeping the amount of feed consumed in the 12 hours of daily assessment, confirmed by the lack of effect $(\mathrm{P}>.05)$ for DM intake (Table 2).

This result can be even justified by feeding period, which was influenced $(\mathrm{P}<.05)$ by the levels of detoxified castor bean meal and resulted in a quadratic effect $(\mathrm{P}<$ .05 ), with a minimum of 5.59 feeding periods, when $62 \%$ of the coproduct was included in the diet (Table 2), indicating a virtual increase of feeding efficiency for DM and NDF, since the sheep reduced the access to the trough, but increased in proportion to the amount of food ingested at each access.

Rumination efficiency, in $\mathrm{g} \mathrm{DM}$ and NDF/minute was not influenced $(\mathrm{P}>.05)$ by the substitution levels of soybean meal by detoxified castor bean meal, with averages of 4.31 and 1.84, respectively (Table 2), which may be linked to the fact that diets are ground, thus reducing the possible effects of DM and, above all, the NDF on rumination events.

The values obtained in this study for rumination efficiency in $\mathrm{g} D \mathrm{DM} / \mathrm{h}$ corroborates those verified by Vieira et al. (2011), who found no significant difference for this parameter when soybean meal was substituted by DCBM at the levels of $0 ; 50 ; 75$ and $100 \%$ with respective means of 198.06; 202.75; 197.14 and 224.19 g DM/hour.

\section{CONCLUSIONS}

The substitution of soybean meal by detoxified castor bean meal reduces the time spent in feeding when using $60 \%$ in the diet, but does not influence the intake of DM and NDF, the time spent on rumination and idleness, and total chewing time, with recommendation of using up to this level, by raising the feeding efficiency of DM and NDF and did not compromise the rumination efficiency. 


\section{REFERENCES}

ANP - Agência Nacional do Petróleo, Gás Natural e Biocombustíveis (2009) Biocombustível. Disponível em: 〈www.anp.gov.br〉. Acessado em: 14 de junho de 2014.

Anandan S, Anil Kumar GK, Ghosh J \& Ramachandra KS (2005) Effect of different physical and chemical treatments on detoxification of ricin in castor cake. Animal Feed Science and Technology, 120:159-168.

Aslani MR, Maleki M, Mohri M, Sharifi K, Najjar-Nezhad V \& Afshari E (2007) Castor bean (Ricinus communis) toxicosis in a sheep flock. Toxicon, 49:400-406.

Brasil (2005) Lei número 11.097, de 13 de Janeiro de 2005. Dispõe sobre a introdução do biodiesel na matriz energética brasileira. DOU, 14/01/2005, Seção 1, p.08.

Cardoso AR, Pires CC, Carvalho S, Galvani DB, Jochims F, Hastempflug M \& Wommer TP (2006) Consumo de nutrientes e desempenho de cordeiros alimentados com dietas que contêm diferentes níveis de fibra em detergente neutro. Ciência Rural, 36:215-221.

Carvalho GGP, Pires AJV, Silva RR, Veloso CM \& SilvaI HGO (2006) Comportamento ingestivo de ovinos alimentados com dietas compostas de silagem de capim-elefante amonizada ou não e subprodutos agroindustriais. Revista Brasileira de Zootecnia, 35:1805-1812

Gowda NKS, Dintaran TP, Srinivas RB, Ujala B, Manpal S, Mayasandra LS, Cadaba SP, Koodli SR \& Koratikere TS (2008) Evaluation of castor (Ricinus communis) seed cake in the total mixed ration for sheep. Society of Chemical Industry, 89:216-220.

Hübner CH, Pires CC, Galvani DB, Carvalho S, Jochims F, Wommer TP \& Gasperin BG (2008) Comportamento ingestivo de ovelhas em lactação alimentadas com dietas contendo diferentes níveis de fibra em detergente neutro. Ciência Rural, 38:10781084 .

Macedo CAB, Mizubuti IY, Moreira FB, Pereira ES, Ribeiro ELA, Rocha MA, Ramos BMO, Mori RM, Pinto AP, Alves TC \& Casimiro TR (2007) Comportamento ingestivo de ovinos recebendo dietas com diferentes níveis de bagaço de laranja em substituição à silagem de sorgo na ração. Revista Brasileira de Zootecnia, 36:1910-1916.
NRC - National Research Council (2007) Nutrient requirements of small ruminants: sheep, goats, cervids, and new world camelids. Washington, National Academy Press. 362p.

Oliveira AS, Campos JMS, Oliveira MRC, Brito AF, Valadares Filho SC, Detmann, Valadares RFD, Souza SM \& Machado OLT (2010) Nutrient digestibility, nitrogen metabolism and hepatic function of sheep fed diets containing solvent or expeller castorseed meal treated with calcium hydroxide. Animal Feed Science and Technology, 158:15-28.

SAS Institute Inc. (2001) Statistical Analysis System user's guide. Version 9.0. Cary, Statistical Analysis System Institute. CD-ROM.

Silva DC, Alves AA, Vasconcelos VR, Nascimento HTS, Filho MAM \& Oliveira ME (2010) Metabolismo dos compostos nitrogenados em ovinos alimentados com dietas contendo farelo de mamona destoxificado. Acta Scientiarum. Animal Sciences, 32:219-224.

Silva DJ \& Queiroz AC (2002) Análise de Alimentos: métodos químicos e biológicos. $3^{\mathrm{a}}$ ed. Viçosa, UFV. 235p.

Silva RR, Magalhães AF, Carvalho GGP, Silva FF, Franco IL, Nascimento PV \& Bonomo P (2004) Comportamento ingestivo de novilhas mestiças de holandês suplementadas em pastejo de brachiaria decumbes. Aspectos metodológicos. Revista Electrónica de Veterinaria, 5:1-7.

Sniffen CJ, O'connor JD, Van Soest PJ, Fox DG \& Russell JB (1992) A net carbohydrate and protein system for evaluating cattle diets: II. Carbohydrate and protein availability. Journal of Animal Science, 70:3562-3577.

Vieira MMM, Cândido MJD, Bonfim MAD, Severino LS, Pereira ES, Beserra LT, Meneses AJG \& Fernandes JPB (2011) Comportamento ingestivo de ovinos alimentados com rações contendo quatro níveis de inclusão de farelo de mamona. Revista Ceres, 58:444-452. 